\title{
Characterization of space around Japanese traditional buildings: transitions of layout plan and meaning of space of darkness inside wooden temples
}

\author{
M. Yasuhara \& T. Sakiyama \\ Department of Architecture and Environment Systems, \\ Akita Prefectural University, Japan
}

\begin{abstract}
Transitions of layout plans of Japanese traditional wooden temple buildings started in Asukadera Temple Compound in 588 A.D. In this temple compound, the Pagoda (Tower) and the Main Hall (Golden Hall, Kondo) are surrounded by Peristyle (Kairo). The Pagoda and the Main Hall are placed inside the Peristyle and the court.

The buildings (Pagoda and Main Hall) surrounded by the Peristyle are important constituents of the temple buildings. Initially, the Pagoda used to be placed in the center. In the next transition stage, the Pagoda and the Main Hall stand parallel side by side. In the next stage, the Main Hall is placed in the center. In the following stage, the Main Hall is still the principal building of the layout, but the Pagoda goes outside of the Peristyle. Thus, the importance of buildings shifted from the Pagoda to the Main Hall.

There are common characteristics among the Japanese traditional temple buildings, such as the Pagoda and the Main Hall, which have a huge space of darkness inside the building. Except for the first floor of the building, there exist only structural members without any floors. Furthermore, facades of the buildings have dummy windows, which cannot be opened to let the air and the natural light come in. It means these windows are meant merely for their external appearance. Thus, these buildings are designed only for the facade without giving any consideration to the interior space, except for the first floor.
\end{abstract}

Keywords: space of darkness, temple, Horyuji, tower, Pagoda, peristyle, history of architectural space, traditional architecture, corner detail, façade, center. 


\section{Transitions of layout plans of Japanese traditional temple wooden buildings and the center of the compound}

Transitions of layout plans of Japanese traditional temple buildings in order of the time of completion are as follows. These transitions started in the Asukadera Temple Compound.

\subsection{Asukadera Temple Compound since 588 A.D.}

At the center of the Asukadera Temple Compound (Fig. 1) there is a court in which the Pagoda (Tower) is surrounded by three Main Halls (Golden Hall, Kondo). The Pagoda (Tower) is more precious than the Main Hall (Kondo). There is one Pagoda, which is situated in the center of the buildings as well as the court. It means the main building is the Pagoda (Tower) in this compound.

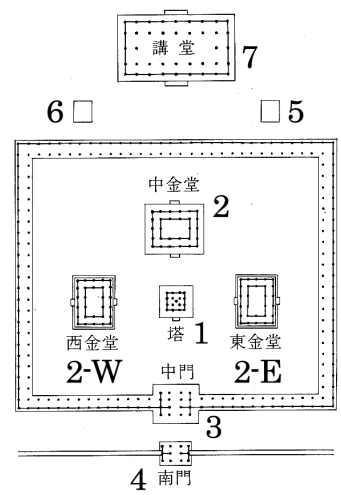

Key:

1 Pagoda (Tower)

1-W West Pagoda (Tower)

1-E East Pagoda (Tower)

2 Main Hall (Golden Hall, Kondo)

2-W West Main Hall (West Kondo)

2-E East Main Hall (East Kondo)

3 Middle Gate (Chumon)

4 South Gate (Nanmon)

5 Sutra Storage (Kyouzou)

6 Bell Tower (Syourou)

7 Lecture Hall (Koudou)

Figure 1: Asukadera Temple Compound.

\subsection{Shitennoji Temple Compound in the beginning of the 7th century}

In the Shitennoji Temple Compound (Fig. 2), the Pagoda (Tower) is placed in front of the Main Hall (Kondo), which people cannot see from the South Gate side (Nanmon, Fig. 3). Still, the Pagoda (Tower) is more precious than the Main Hall (Kondo). However, even in the Pagoda (Tower), what people can see is only the top of it through the South Gate (Nanmon, Fig. 3).

\subsection{Horyuji Temple, West Compound (Saiin) at the end of the 7th century}

In the Horyuji Temple West Compound (Fig. 4, Fig. 10), the Pagoda (Tower) and the Main Hall (Kondo) are flanked side-by-side breaking left-right symmetry. This layout means that both buildings are equivalently considered as a precious building. 

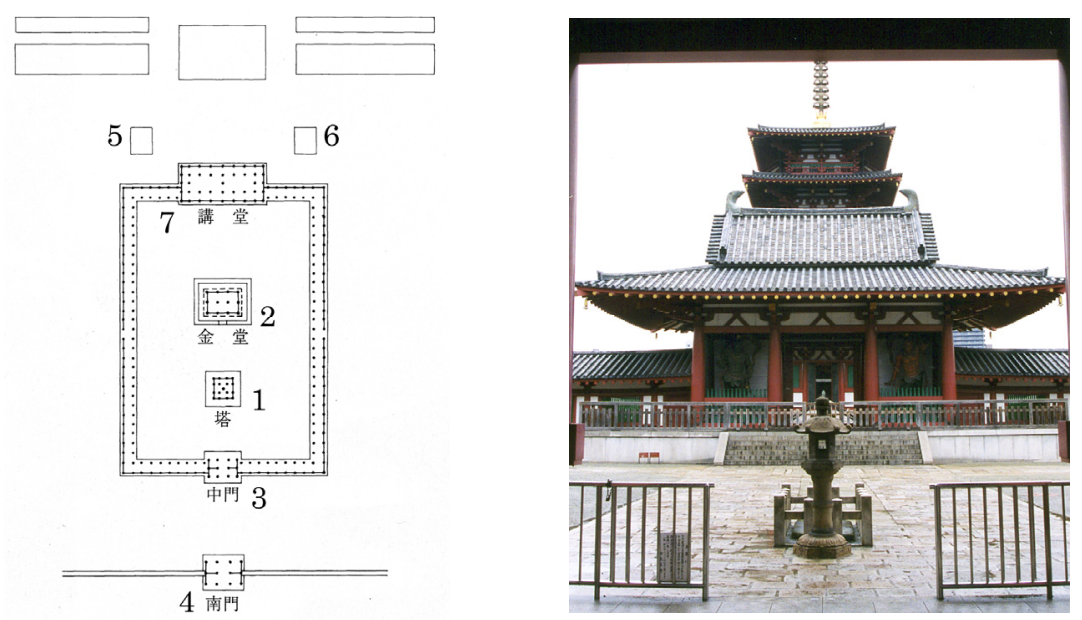

Figure 2: $\quad$ Shitennoji Temple Figure 3:

From the South Gate in Compound. Shitennoji Temple.

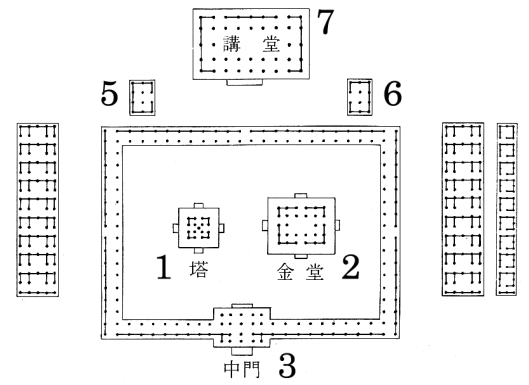

Figure 4: $\quad$ Horyuji Temple, West Compound.

\subsection{Yakushiji Temple Compound in the first half of the 8th century}

In the Yakushiji Temple Compound (Fig. 5), the Main Hall (Kondo) is situated in the central part of the court and also among buildings. In front of the Main Hall (Kondo) there are two Pagodas (Towers) side by side. In comparison with the Pagodas (Tower), the Main Hall (Kondo) is taken as the most important building.

\subsection{Kofukuji Temple Compound since the 8th century}

In the Kofukuji Temple Compound (Fig. 6), the Main Hall (Kondo) is connected with the Peristyle (Kairo) from where the Tower is placed outside. In the court there are no buildings. The Main Hall (Kondo) becomes the most important 


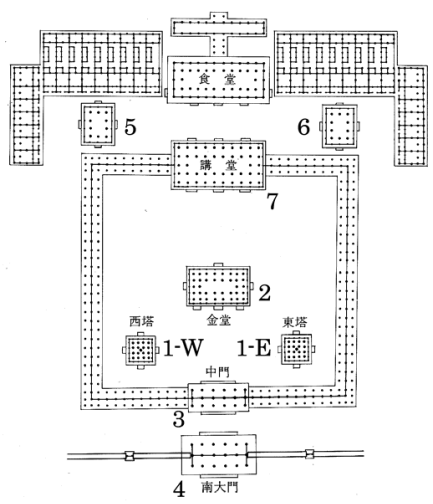

Figure 5: $\quad$ Yakushiji Temple Compound.

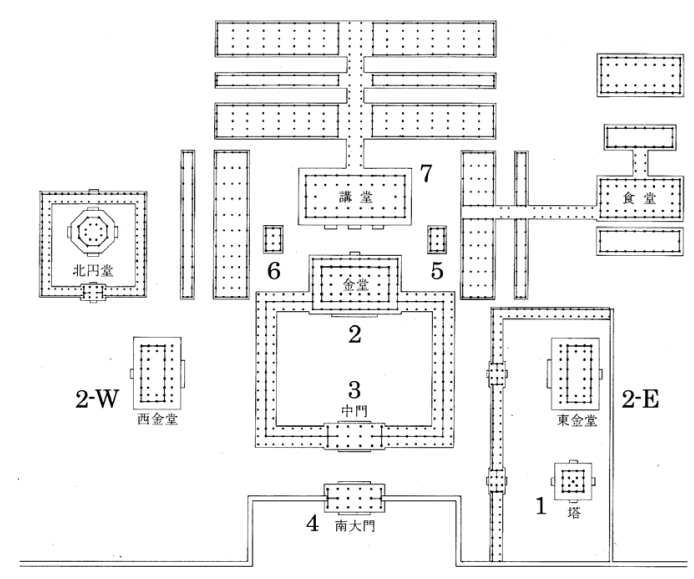

Figure 6: Kofukuji Temple Compound.

building in this compound, and the Compound has a spacious court for religious functions, which are taken as the important factor in the temple Compounds since about the 8 th century.

\subsection{Todaiji Temple Compound since 751 A.D.}

In the Todaiji Temple Compound (Fig. 7), similar trends like that of the Kofukuji Temple Compound are found, i.e. the Pagodas (Towers) are placed outside of the Peristyle (Kairo). The Main Hall (Kondo) is still the most important building in the compound.

\section{Meaning of the transitions}

The buildings (Pagoda and Main Hall) surrounded by the Peristyle are important constituents of the temple buildings. Initially, the Pagoda used to be placed in the 


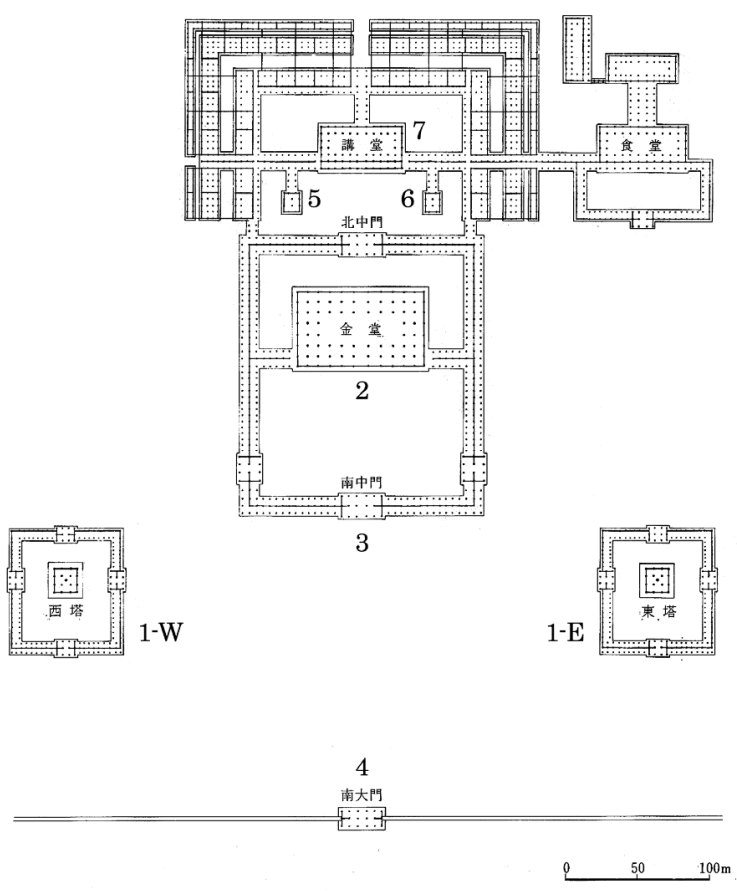

Figure 7: $\quad$ Todaiji Temple Compound.

center of buildings and the court. In the next transition stage, the Pagoda and the Main Hall (Kondo) stand parallel side by side. In the next stage, the Main Hall (Kondo) is placed in the center. In the following stage, the Main Hall (Kondo) is still the principal building of the layout, but the Pagoda goes outside of the Peristyle (Kairo). Thus, the importance of buildings shifted from the Pagoda (Tower) to the Main Hall (Kondo).

Originally, the Pagoda was the grave of Buddha, which has no interior space. Underneath the central column in the Pagoda, the relics of Buddha are installed. The grave was worshiped from the outside. That is why it is natural even if there is small limited inside space of Pagodas (Tower, Fig. 8) in Japan. The Main Hall (Kondo) is the building to enshrine the main statue of Buddha, and there is also small limited inside space of the Main Hall (Fig. 9). Both buildings are very important to the temple.

This means, in the transitions of layout plans of Japanese traditional temple buildings, the heart of the faith to the temple shifted from the relics of Buddha to the main statue of Buddha.

\section{The characteristics of the central buildings}

The roof style of the Pagoda (Tower) has a square hipped roof, and the Main Hall (Golden Hall, Kondo) has a half-hipped roof or hipped roof (Fig. 10). 

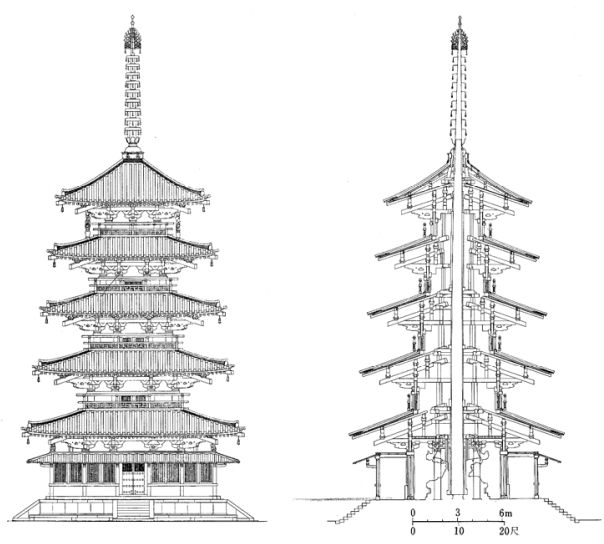

Figure 8: The elevation and the section of the Pagoda in Horyuji Temple.
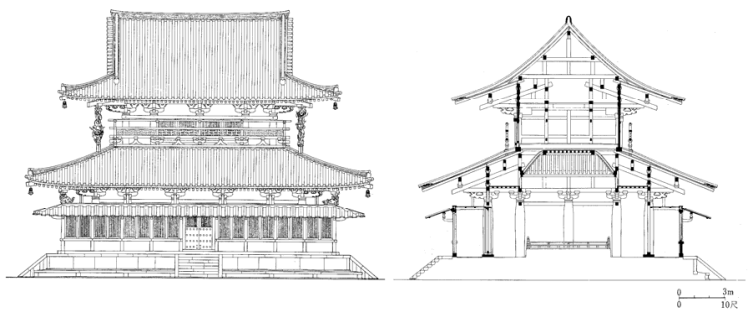

Figure 9: The elevation and the section of the Main Hall in Horyuji Temple.

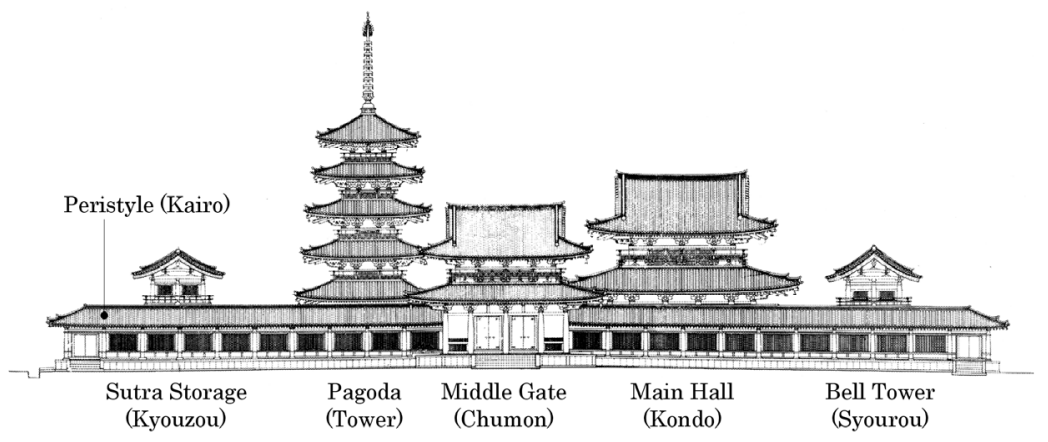

Figure 10: The elevation of Horyuji Temple.

The temple buildings are the center of their region. These buildings show their own existence, the shape and the skyline around the compound from a long distance (Fig. 11); therefore, the shapes of each building demand certain height and refined detail that can be seen from everywhere around. The facades of the Pagoda (Tower) and the Main Hall (Kondo) face the outside of the compound and also the court surrounded by the Peristyle (Kairo). 


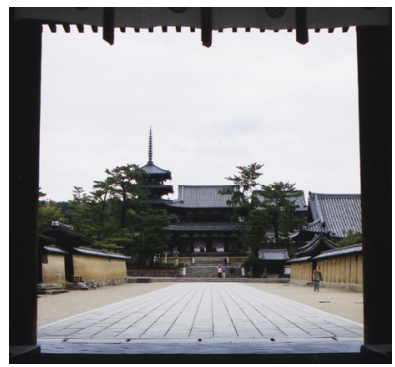

Figure 11: The approach from the South Big Gate in Horyuji Temple.

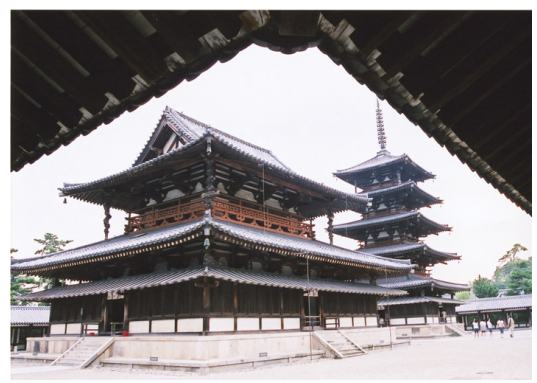

Figure 12: The Main Hall and the Pagoda in Horyuji Temple.

From the court and the Peristyle (Kairo) people can see not only the height of the buildings, but also the details of the Pagoda (Tower) and the Main Hall (Kondo), which are the main buildings in the compound. The Pagoda (Tower) and the Main Hall (Kondo) have a square floor plan, which has four corners. The corner details toward four corners are refined carefully. That is why these buildings can be seen not only from a long distance, but also from a short distance, such as from the court and the Peristyle (Kairo).

The compound surrounded by the Peristyle (Kairo) has the high grade of space refined like the Pagoda (Tower) and the Main Hall (Kondo) because of being exposed to the eyes of the priest, aristocrat, visitors to the temple and general people (Fig. 12). Thus, the corner detail is refined, and perfect details of the four corners are obtained. Only such kind of high-grade buildings remained in the court. People viewed these buildings from every direction of the court and the Peristyle (Kairo).

The underside of the eaves also demands complete corner details, which can be viewed from both directions of the corners. Ogidaruki has the rafter placement in the fan pattern at the corner, like Shitennoji Temple (Fig. 13) and the South Big Gate (Nandaimon) of Todaiji Temple (Fig. 14). Heikodaruki has the rafter placement in the parallel style (Fig. 15). Both fan pattern rafter placement (Ogidaruki) and parallel pattern rafter placement (Heikodaruki) are the form to be refined to the view from every direction. 
However, parallel pattern rafter placement (Heikodaruki) is accepted popularly in Japan. When people approach the facade the parallel line of rafter placement can allow the flow line of people's approach to be straight. Most Japanese traditional temple buildings accept this style of rafter placement (Heikodaruki) prevailingly.

The buildings with the gabled roof, which have a different appearance at the front and the side, are placed to the outside of the Peristyle (Kairo). These are the Bell Tower (Syourou, Fig. 16, Fig. 10) and the Sutra Storage (Kyouzou, Fig. 10. See plans. Figs. 1-7). The roof style with same four corner detail is not the gabled roof but the hipped roof. In the early stage, buildings with the same four corners detail remained in the court.

That is why the Peristyle (Kairo) is considered to be an important constituent when observing buildings having four corners with refined detail.

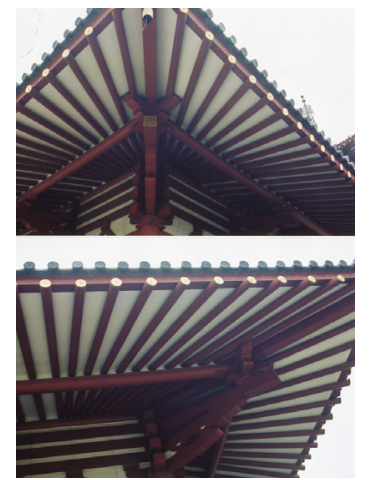

Figure 13: Ogidaruki in Shitennoji Temple.

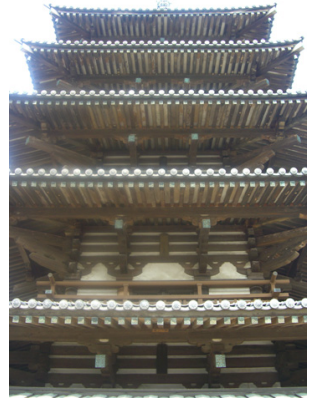

Figure 15: Heikodaruki of the Pagoda in Horyuji Temple.

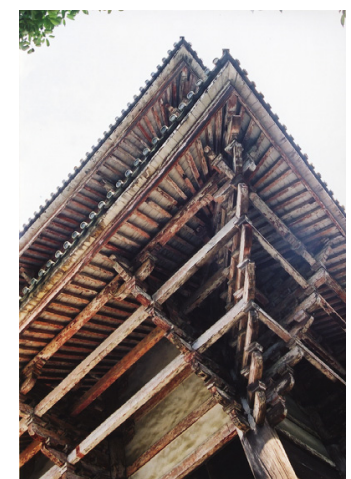

Figure 14: Ogidaruki of the South Big Gate in Todaiji Temple.

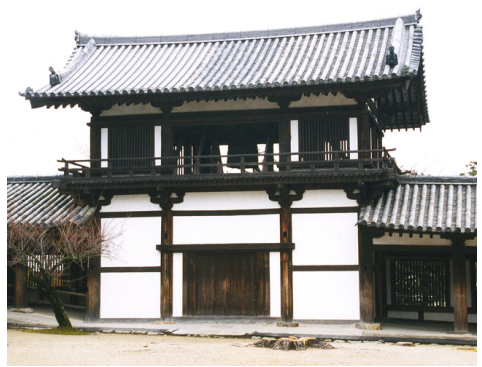

Figure 16:

The Bell Tower (Syourou) in Horyuji Temple. 


\section{Space of darkness inside of the building}

There are the common characteristics in these Japanese traditional temple wooden buildings, such as the Pagoda (Tower) and the Main Hall (Golden Hall, Kondo), which have a huge space of darkness inside the building (Figs. 8 and 9). That space is larger than the space for functional use, especially in the Pagoda, and sometimes in the Main Hall (Fig. 9). Another specific case is in the Zaoudou (Main Hall, Hondo, Fig. 17) of Kinpusenji temple in the beginning of the 12th century and rebuilt in 1588 .

Although the building of the European church (basilica style church, Gothic style church, Fig. 18) has such a kind of space of darkness, they occupy a small volume as compared to the Japanese traditional temple buildings, as the ratio of volumes between space of darkness and space for use is different.

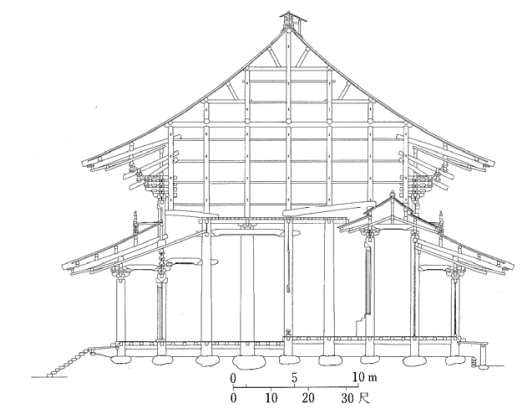

Figure 17: Zaoudou (Main Hall, Hondo) in Kinpusenji Temple.

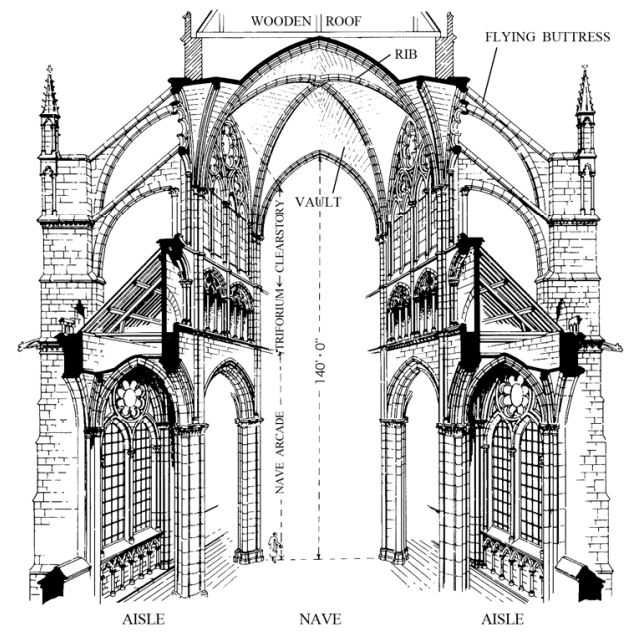

Figure 18: Space of darkness in Gothic style church. 
The existence of a large space of darkness inside the building is characteristic of Japanese traditional wooden temple buildings.

\section{Concluding remarks}

The interiors of the Pagoda (Tower, Fig. 8) and the Main Hall (Golden Hall, Kondo, Fig. 9) are filled with a space of darkness. In particular, in those buildings that have more than two stories, the floors beyond the second level are not functionally used. In most of these buildings, interior space higher than the second level of floor is occupied by structural wooden members to support the external form (Figs. 8 and 9). That is why the appearance and facade of the building are thought important by letting the structure be exposed to internal space. Timbers extended from inside space of the building support the outside appearance with roofs and eaves. Japanese traditional wooden buildings (temples) have long eaves on every roof level.

In regards to the buildings that are higher than two stories, an abundance of structural timbers makes the inside of the buildings crowded and there exists no floors. This implies that the Pagoda (Tower, the Gojyu-no-to) is not a five-story building, but rather a one-story building (Fig. 8). Similarly, the Main Hall (Kondo) is not a two-story building but a one-story building (Fig. 9). In the space of darkness people cannot walk because of the non-existence of floors and also cannot move due to barriers imposed by the abundant existence of structural timbers.

In Butsuguji Temple of China there is a five-story wooden Pagoda (1056, Fig. 19), which has five floors with shorter eaves. Every floor is used functionally. Shorter eaves do not need strong and large scale structural timber framework. This is rational thinking for buildings in China. Therefore, there are a lot of differences between the Japanese traditional temple buildings and their Chinese counterparts.

In Japan the Pagoda (Tower, Fig. 8) and the Main Hall (Kondo, Fig. 9) look like several-story buildings, but they have only one story. That is why these buildings are designed for the facades with which refined details of outside are needed. As precious buildings like the Pagoda and the Main Hall (Kondo) are surrounded by or connected with the Peristyle (Kairo) and the court, this is from where the visitors to the temple look around in the short distance. In many Japanese traditional temple buildings, the space of darkness is bigger than the volume of space used functionally. The ceiling of the first floor seals the space of darkness upward, therefore inside of it is pitch-dark.

Furthermore, the facades of the buildings have dummy windows (Fig. 8), which cannot be opened to let the air and the natural light come in. It means these windows are meant merely for their external appearance. It is questionable as to why such kind of space of darkness and dummy windows exist in Japanese traditional temple buildings.

It can be thought that these buildings are designed for the facades without giving any consideration to the interior space except for the first floor. As the 


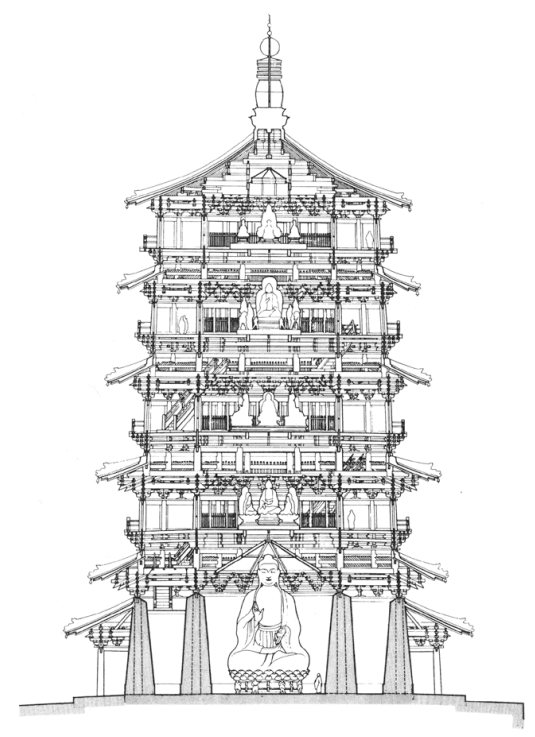

Figure 19: The section of the Pagoda at Butsuguji Temple in China.

refined facades are needed, a huge space of darkness for the structure is accepted inside of the building. This is because there are only structural wooden members for the roofs without any floors with long eaves, which have to be supported.

\section{References}

[1] Yasuhara, M., Research about Viewpoints of Space around Japanese Traditional Buildings, Research Reports of the Architectural Institute of Japan, Tohoku Branch, No.58, pp.51-58, 1995 (in Japanese).

[2] Yasuhara, M., Japanese Space in Architecture, Shinpu-syobou Publishing Co., Ltd.: Osaka, 1996 (in Japanese).

[3] Yasuhara, M., Characterization of Space around Japanese Traditional Buildings. Part 1. The Case of Horyuji Temple, FORMA, Vol.12 No.1, pp. 65-70, The Society for Science on Form, Japan, 1997.

[4] Yasuhara, M., Characterization of Space around Japanese Traditional Buildings. Part 2. The Physical and Psychological Effects of View of Eaves. FORMA, Vol.12 No.1, pp.71-74, The Society for Science on Form, Japan, 1997.

[5] Yasuhara, M., Space of Modern Architecture in Japan, Riko-tosyo Publishing Co., Ltd.: Tokyo, 1998 (in Japanese).

[6] Yasuhara, M., Reading the Space from the Tale of Genji, Kajima Institute Publishing Co., Ltd.: Tokyo, 2000 (in Japanese).

[7] Yasuhara, M., Doctoral Dissertation, Researches Concerning the Characteristics of Space in the Shinden Residence Reading from the Tale of Genji. 2001 (in Japanese). 
58 Structural Studies, Repairs and Maintenance of Heritage Architecture XI

[8] Yasuhara, M., Space of SHINDEN Residential Complex (SHINDENZUKURI). Part 1. Lighting from the side. FORMA, Vol.16 No.4, pp.367374, The Society for Science on Form, Japan, 2002.

[9] Yasuhara, M., Introduction to Architecture (Chapter 3 "History of Architectural Space in Japan"), Gakugei Publishing Co., Ltd.: Kyoto, 2003 (in Japanese).

[10] Yasuhara, M., Reading the Space from Seiichi Shirai's Architecture, Gakugei Publishing Co., Ltd.: Kyoto, 2005 (in Japanese). (Seiichi Shirai is a Japanese Architect)

[11] Yasuhara, M., Reading haiku poet Basho from Narrow Roads to Oku, Kajima Institute Publishing Co., Ltd.: Tokyo, 2006 (in Japanese).

[12] Yasuhara, M., Characterization of Space around Japanese Traditional Buildings. "Visible Music" on the approach to Horyuji Temple, Saiin (West Compound), Structural Studies, Repairs and Maintenance of Heritage Architecture X, pp. 53-60, STREMAH X (2007) Wessex Institute.

[13] Yasuhara, M., History of Architectural Space in Europe-Composition of Wall-, Kajima Institute Publishing Co., Ltd.: Tokyo, 2007 (in Japanese).

[14] Yasuhara, M., History of Architectural Space in Europe, second seriesTransition from Wall to Column-, Kajima Institute Publishing Co., Ltd.: Tokyo, 2009 (in Japanese). 